University of Nebraska - Lincoln

DigitalCommons@University of Nebraska - Lincoln

Publications from USDA-ARS / UNL Faculty

U.S. Department of Agriculture: Agricultural

Research Service, Lincoln, Nebraska

September 1978

\title{
Leaf Growth, Leaf Aging, and Photosynthetic Rate of Tall Fescue Genotypes
}

Wallace Wilhelm

University of Nebraska-Lincoln, wwilhelm1@unl.edu

C. J. Nelson

USDA

Follow this and additional works at: https://digitalcommons.unl.edu/usdaarsfacpub

Part of the Agricultural Science Commons

Wilhelm, Wallace and Nelson, C. J., "Leaf Growth, Leaf Aging, and Photosynthetic Rate of Tall Fescue Genotypes" (1978). Publications from USDA-ARS / UNL Faculty. 126.

https://digitalcommons.unl.edu/usdaarsfacpub/126

This Article is brought to you for free and open access by the U.S. Department of Agriculture: Agricultural Research Service, Lincoln, Nebraska at DigitalCommons@University of Nebraska - Lincoln. It has been accepted for inclusion in Publications from USDA-ARS / UNL Faculty by an authorized administrator of DigitalCommons@University of Nebraska - Lincoln. 


\title{
Leaf Growth, Leaf Aging, and Photosynthetic Rate of Tall Fescue Genotypes ${ }^{1}$
}

\author{
W. W. Wilhelm and C. J. Nelson ${ }^{2}$
}

\begin{abstract}
Leaf growth and leaf aging both influence the total amount of $\mathrm{CO}_{2}$ fixed by a particular leaf in the canopy during its photosynthetically productive life. Four genotypes of tall fescue (Festuca arundinacea Schreb.) were selected for all combinations of high and low $\mathrm{CO}_{2} \mathrm{ex}$ change rates (CER) and yield. The purpose of this study was to determine CER during aging and leaf growth rates of tall fescue genotypes in growth chambers and in the field on a Mexico silt loam (Udollic Ochraqualfs; fine, montmorillonitic, mesic). Leaf growth of vegetative tillers in controlled environments was continuous through. out the day for all genotypes, regardless of CER or yield performance; however, leaf growth rate during a 24-hour period changed diurnally in response to altered temperature and plant water status. Average leaf elongation rates were greater in the field during autumn $(8.2 \mathrm{~mm}$ day) than in summer $(4.2 \mathrm{~mm} / \mathrm{day})$. In both field and growth-chamber studies, high-yielding genotypes exhibited approximately $50 \%$ greater rates of both leaf elongation and leaf area expansion than did low-yielding genotypes. During 4 weeks in a growth chamber and 6 weeks in the field, CER of all four genotypes decreased after collar formation at a rate of about 15 to $20 \%$ per week. Leaf diffusive resistances were similar for all genotypes and increased during aging from $1.42 \mathrm{sec} / \mathrm{cm}$ to $3.56 \mathrm{sec} / \mathrm{cm}$ in both studies. Genotypes with faster rates of leaf area development should reach critical leaf area index (LAI) faster than those with slow rates. They also would have relatively younger leaf tissue in the upper canopy, which is more efficient photosynthetically than older leaf tissue.
\end{abstract}

Additional index words: Leaf diffusive resistance, Leaf elongation, Festuca arundinacea Schreb., $\mathrm{CO}_{2}$ ex change rate.

A $\mathrm{N}$ inconsistent relationship between forage yield and $\mathrm{CO}_{2}$ exchange rates (CER) of single leaves among tall fescue (Festuca arundinacea Schreb.) genotypes has been reported (Nelson et al., 1975). They suggested that factors such as genotypic variation in leaf aging and canopy architecture may have a dominant influence on dry matter production of each genotype, regardless of CER. Wilhelm and Nelson (1978) selected genotypes of tall fescue with combina-

\footnotetext{
${ }^{1}$ Contribution from the Missouri Agric. Exp. Stn. Journal Series 8013. Received 18 Jan. 1978.

${ }^{2}$ Graduate assistant (now plant physiologist, SEA-AR-USDA Lincoln, NE 68583) and professor of agronomy, Dep. of Agronomy, Univ, of Missouri-Columbia, Columbia, MO 65201 .
}

tions of high and low forage yield and high and low CER. Responses of CER to variation in photosynthetic photon flux density were similar among genotypes. Diurnal patterns of CER were also similar among genotypes.

Treharne and Eagles (1970) noted that both winterdormant and nondormant populations of orchardgrass (Dactylis glomerata L.) maintained photosynthetic rates of 12 to $24 \mathrm{mg} \mathrm{CO}_{2} \mathrm{dm}^{-2}$ hour $^{-1}$ at $5 \mathrm{C}$. However, the winter-dormant population ceased production of leaf tissue and utilized the photosynthate as storage carbohydrates, whereas the actively growing population did not accumulate carbohydrates and continued using assimilate for leaf growth (Eagles, 1967). Dry-matter production has been shown to be more closely related to leaf growth and leaf area increase than to photosynthetic rates per unit leaf area (Hanson, 1971; Yoshida, 1972; Rhodes, 1972; Hoveland et al., 1974).

We hypothesized that differences in yield exhibited by tall fescue genotypes with similar CER determined by short-term, midday measurements may be a result of genotypic differences in the influence of leaf age on CER between genotypes, i.e., the rate of decline in CER with increased age may be greater in the low. yielding genotype than in the high. Therefore, the total amount of $\mathrm{CO}_{2}$ fixed by a unit of leaf area during its photosynthetically productive life may not be equal, as suggested by CER measurements, and yields would logically differ. The objectives of this research were to test this hypothesis and to determine the influence of leaf growth and leaf age on the CER-yield relationships among selected genotypes of tall fescue.

\section{MATERIALS AND METHODS}

\section{Leaf Aging}

Four genotypes of tall fescue were selected (Wilhelm and Nelson, 1978) to represent four CER-yield categories: high CER-high yield $(\mathrm{H}-\mathrm{H})$, high CER-low yield (H-L), low CERhigh yield (L-H), and low CER-low yield (L-L). For two separate experiments, three vegetative tillers of each genotype were planted in $10-\mathrm{cm}$ diam by $15-\mathrm{cm}$ deep plastic pots filled with Mexico silt loam top soil. Plants were allowed to grow in the greenhouse at $25 \pm 5 \mathrm{C}$ for approximately 2 months before being transferred to a controlled environment chamber with $20 / 15 \mathrm{C}$ (light/dark) temperature and greater than $50 \%$ relative humidity. A 14-hour photoperiod of $500 \mu \mathrm{E} \mathrm{m} \mathrm{m}^{-2} \mathrm{sec}^{-1}$ 


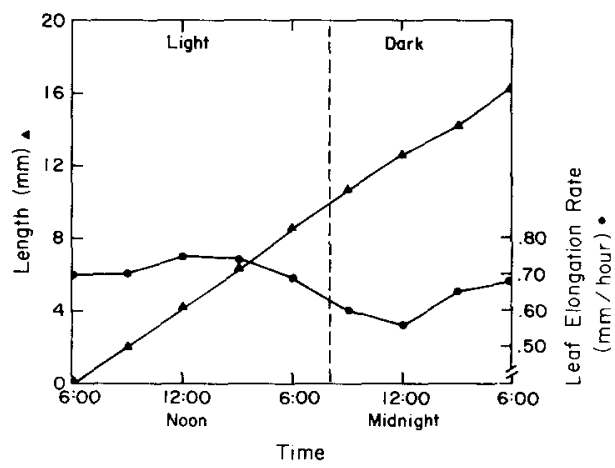

Fig. 1. Diurnal pattern of increase in leaf length and leaf elongation rate averaged over four tall fescue genotypes.

photosynthetic photon flux density was provided by cool-white fluorescent and incandescent bulbs. Plants were maintained in a well-watered condition and supplemented with $50 \mathrm{ml}$ of a complete nutrient solution (Epstein, 1972) each week.

Plants were cut to $6 \mathrm{~cm}$ above the soil level to start the experiment following a 2-week acclimatization period in the growth chamber. When new leaves were 10 to $15 \mathrm{~cm}$ long, two young, actively growing leaves/pot were selected and labeled with small, colored wires placed around the culm immediately below the leaf blade to be measured. Carbon dioxide exchange rate of the leaf blade was measured weekly by infrared gas analysis using the air-sealed, leaf-chamber system described by Nelson et al. (1974).

Leaf diffusive resistance of the abaxial lamina surface was measured using a diffusion porometer, Lambda Instruments LI-60 (Kanemasu et al., 1969), on the same leaf tissue immediately after each CER measurement. Leaf area was determined in situ for CER calculations by multiplying the length of the measured portion of the labeled leaves by the midwidth. Measurements were made for 5 consecutive weeks on the same leaves

Leaf aging patterns of the four genotypes were also studied in $0.5-$ by $1.5-\mathrm{m}$ field plots during autumn 1975. Plots had been established on a Mexico silt loam (Udollic Ochraqualfs; fine, montmorillonitic, mesic) and originally consisted of 33 sprigs of each genotype in three rows $25 \mathrm{~cm}$ apart, with plants $15 \mathrm{~cm}$ apart in the rows (Wilhelm and Nelson, 1978). Plots were arranged in a randomized, complete block design with four replications and had developed a sward condition. Six actively growing leaves per plot were chosen on 29 Sept. 1975 and labeled as above for later identification. Plants had been regrowing for 4 weeks when leaves were selected. Leaf diffusive resistance, CER, and leaf area were measured at approximately 1-week intervals as above on clear days for 6 consecutive weeks.

\section{Diurnal Leaf Growth}

For two separate experiments, three vegetative tillers of each of the genotypes selected above were planted in pots constructed of $38-\mathrm{cm}$ lengths of $10-\mathrm{cm}$-diam plastic drain pipe with pegboard bottoms to allow for adequate drainage. Plants were grown in a greenhouse for approximately 10 weeks before being moved to a controlled-environment chamber with light and temperature conditions described above.

After a 2-week acclimatization period, top growth was cut to $6 \mathrm{~cm}$ above the soil level, and plants were allowed to regrow for approximately 10 days. At this time three young, actively growing leaves per pot were labeled in each of the four replications. Leaf lengths were measured every 3 hours from 1500 hours, 16 Feb. 1975 , until 1500 hours, 18 Feb. 1975, during the first experiment, and from 1500 hours, 30 Sept. 1975, until 1800 hours, 2 Oct. 1975, during the second experiment.

Leaf length was measured from the tip of the elongating leaf to the collar of the previously fully expanded leaf. Width of the elongating leaf was determined after the last length measurement. Rates of leaf elongation $(\mathrm{mm} / \mathrm{hour})$ and leaf

\footnotetext{
${ }^{3}$ Mention of a trademark or proprietary product does not constitute a guarantee or warranty of the product by USDA or the Missouri Agric. Exp. Stn. and does not imply their approval to the exclusion of other products that may be suitable.
}

Table 1. Mean leaf elongation rate, leaf width, and leaf area expansion rate of four tall fescue genotypes grown under a controlled environment. Genotypes were selected for high $(\mathbf{H})$ and low (L) $\mathrm{CO}_{2}$ exchange rate (CER) and yield.

\begin{tabular}{cccc}
\hline Genotype & $\begin{array}{c}\text { Leaf } \\
\text { elongation }\end{array}$ & Leaf width & $\begin{array}{c}\text { Leaf area } \\
\text { expansion }\end{array}$ \\
\hline CER-yield & mm/hour & $\mathrm{mm}$ & mm²/hour $^{2}$ \\
H-H & 0.90 & 5.98 & 5.50 \\
H-L & 0.45 & 4.96 & 2.22 \\
L-H & 0.74 & 5.46 & 4.09 \\
L-L & 0.55 & 5.54 & 3.12 \\
L.S.D. (0.05) & 0.12 & 0.62 & 1.01 \\
\hline
\end{tabular}

area expansion (leaf elongation $\times$ width, $\mathrm{mm}^{2} /$ hour) were calculated for each 3-hour period and are reported as the growth rate during that time interval.

\section{Long-Term Leaf Growth}

Three young, actively growing leaves in each pot (replication) of the diurnal leaf growth study were labeled, and leaf length was measured as above at least five times at 2 to 3-day intervals until collars appeared. Rate of elongation $(\mathrm{mm} / \mathrm{day})$ was estimated by the linear regression coefficient of leaf length on days. Leaf area expansion $\left(\mathrm{mm}^{2} / \mathrm{day}\right)$ was calculated by multiplying leaf elongation rate by the width of each measured leaf.

Leaf growth rates of the four genotypes were also measured in field plots described above during July and October 1975. Canopies were approximately $25-\mathrm{cm}$ high when leaves were selected and first measurements were taken. Length and width of six young, actively growing leaves per plot were measured as above at 2 to 3 -day intervals until collars were visible. Rates of elongation and expansion were calculated as above.

All data were analyzed using the standard analysis of variance, and means were compared with least significant difference.

\section{RESULTS AND DISCUSSION}

\section{Diurnal Leaf Growth}

Results of the two growth-chamber studies on diurnal leaf growth were very similar and were combined for presentation. The genotype by time interaction was not significant $(P<0.05)$, so leaf length and rate of leaf elongation were averaged over genotypes to obtain a diurnal pattern (Fig. 1). In agreement with data for orchardgrass (Eagles, 1974), leaves increased in length continuously throughout the day (Fig. 1); however, rate of leaf elongation ( $\mathrm{mm}$ /hour) was sensitive to environmental changes during that 24-hour period. Leaf elongation rate declined during the latter part of the light period and showed a further decline at the beginning of the dark period, which coincided with the light/dark temperature change from 20 to $15 \mathrm{C}$. Although plants were well watered, recovery in rate of leaf elongation near the end of the dark period may have been due to improved water status in the entire plant (Wardlaw, 1969; Watts, 1974; Peacock, 1975).

High-yielding genotypes displayed greater leaf elongation rates than low-yielding genotypes (Table 1 ), which is in agreement with field results of Horst (1973). Harvestable dry matter consists mainly of leaf tissue in the postflowering growth stage in tall fescue.

Leaf area expansion rates $\left(\mathrm{mm}^{2} /\right.$ hour $)$ were also found to be significantly different among genotypes (Table 1). Rate of leaf area expansion is largely a function of leaf elongation rate ( $\mathrm{mm} / \mathrm{hour}$ ) and close- 
Table 2. Long-term leaf elongation rates of four genotypes of tall fescue selected for high (H) and low (L) $\mathrm{CO}_{2}$ exchange rate (CER) and yield.

\begin{tabular}{lccc} 
& \multicolumn{2}{c}{ Field } & \\
\cline { 2 - 3 } Genotype & Summer & Autumn & Growth chamber \\
\hline CER-yield & & mm/day \\
H-H & 4.74 & 8.71 & 17.51 \\
H-L & 3.87 & 7.43 & 9.30 \\
L-H & 5.97 & 11.18 & 15.60 \\
L-L & 2.03 & 6.84 & 12.19 \\
L.S.D. (0.05) & 1.53 & 1.96 & 3.94 \\
\hline
\end{tabular}
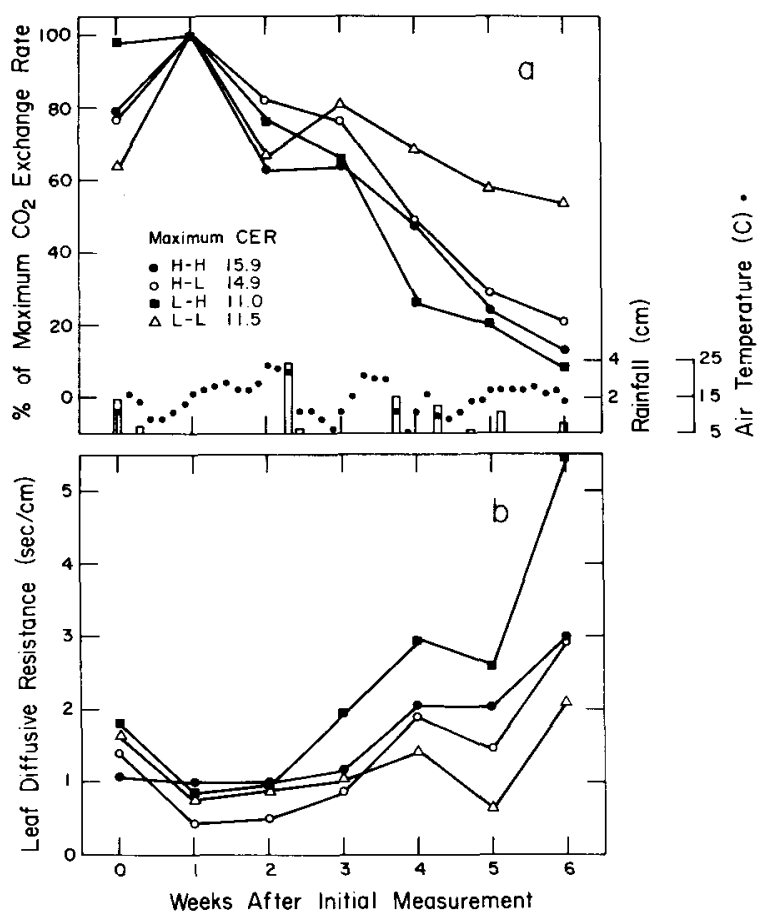

Fig. 2. Relative $\mathrm{CO}_{2}$ exchange rate (a) and leaf diffusive resistance (b) of four tall fescue genotypes measured for 6 consecutive weeks in the field. Genotypes were selected for high (H) and low (L) CER and yield (CER-yield).

ly paralleled rate of leaf elongation (Eagles, 1974). Nelson et al. (1977) have shown that, in a broad-based population of tall fescue, rate of leaf elongation was 1.6 to 1.8 times more critical than leaf width in determining rate of leaf area expansion. The correlation coefficient, over genotypes in this study with similar leaf widths (Table 1), between leaf elongation and leaf area expansion was $0.95(\mathrm{P}<0.01)$. It appeared that measurement of leaf elongation alone was sufficient in determining broad genotype differences in leaf tissue production.

\section{Long-Term Leaf Growth}

Leaf elongation rate measured in the field averaged 8.54 and $4.15 \mathrm{~mm}$ /day during autumn and summer, respectively, for the four genotypes. Environmental factors such as high temperature (Peacock, 1975), combined with decreased plant water status (Wilson, 1975), probably decreased rate of leaf growth in summer. Genotypic differences were consistent from summer to autumn (Table 2).

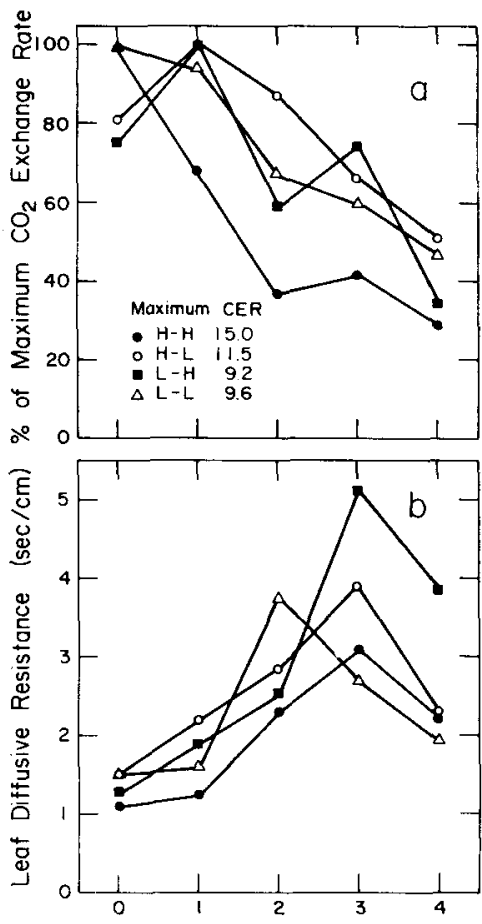

Fig. 3. Relative $\mathrm{CO}_{2}$ exchange rate (a) and leaf diffusive resistance (b) of four tall fescue genotypes measured for 4 consecutive weeks in the growth chamber. Genotypes were selected for high (H) and low (L) CER and yield (CER-yield).

In the field, leaf growth rates of the high-yielding genotypes were about $52 \%$ greater than the low-yielding genotypes (Table 2). In the growth chamber, leaf growth rates of high-yielding genotypes were $54 \%$ greater than low-yielding genotypes. The highest yielding genotype in these studies, L-H, (Wilhelm and Nelson, 1978) was consistently high in leaf growth rate, which supports the conclusion of Horst (1973) that leaf growth rate was closely associated with forage yield.

In these studies it was not determined whether rate of cell division and cell elongation was causing the genotypic differences in leaf growth. However, other studies (Meyer and Boyer, 1972) indicated cell elongation was more sensitive to changes in environmental conditions and, therefore, probably caused the seasonal and diurnal change in leaf elongation rate.

\section{Leaf Aging}

Leaf photosynthesis of both field-grown (Fig. 2a) and growth-chamber plant material (Fig. 3a) was affected similarly by increasing leaf age. In the field experiment, collar formation occurred for the majority of leaves between the Week 1 and Week 2 measurement (Fig. 2). High-yielding genotypes collared about 4 days earlier than the low-yielding genotypes. In the growth chamber (Fig. 3), 67\% of the leaves collared within 2 days of the Week 1 measurement. In both studies, CER was maximum at time of collar formation and decreased with age. Similar results were reported by Jewiss and Woledge (1967). Rate of CER decline was approximately 15 to $20 \%$ per week.

Generally, leaf diffusive resistance increased during aging in both studies (Fig. $2 \mathrm{~b}$ and $3 \mathrm{~b}$ ). In the field 
study, an initial decline in leaf resistance was associated with the period of maximum CER (Fig. 2b). Leaf resistance increased with time in the growthchamber study (Fig. 3b) until the last measurement date. The decrease in leaf resistance at that time was probably associated with leaf senescence and some physical injury, which may have led to loss of stomatal control and an increase in cuticular transpiration (Grace, 1974).

In the growth-chamber study (Fig. 3), the $\mathrm{H} \cdot \mathrm{H}$ genotype showed a greater decline in CER during the initial weeks than other genotypes, but after 4 weeks it had a similar relative rate of CER. This rapid decline in CER early in the leaf ontogeny does not support our hypothesis explaining yield differences between genotypes with similar CER. In the field study, the CER of the L-L genotype declined an average of about $10 \%$ per week (Fig. 2a), while other genotypes decreased approximately $20 \%$ per week. This again appears contrary to our hypothesis.

The results of this study and previous work (Wilhelm and Nelson, 1978) indicate that differences in CER-yield relationships cannot be explained by genotypic variation in photosynthetic photon-flux densityresponse curves, diurnal CER patterns, or leaf aging patterns with respect to CER. However, the leaf growth data presented here may help decipher the underlying causes for differences in the CER-yield relationship among genotypes of tall fescue. Highyielding genotypes also display rapid rates of leaf elongation regardless of CER. Genotypes with rapid leaf growth not only have a yield advantage because leaf tissue is the harvested portion of the plant's total biomass, but it also gives the added advantage of increasing photosynthetic area more rapidly. The more rapid increase in photosynthetic tissue would also maintain a greater amount of young leaf area in the upper part of the plant canopy. With young tissue capable of greater CER, the total amount of $\mathrm{CO}_{2}$ fixed in the canopy would also be greater, regardless of the rate of fixation/unit of leaf area. Consequently, the superior leaf growth rate overshadows the difference in CER and allows a low-CER genotype to exhibit high yield. Conversely, low-yielding genotypes do not have the rapid leaf growth characteristics to capitalize on a high-CER trait.

\section{REFERENCES}

1. Eagles, C. F. 1967. The effect of temperature on vegetative growth in climatic races of Dactylis glomerata in controlled environment. Ann. Bot. 31:31-39.
2. - 1974. Diurnal fluctuation in growth and $\mathrm{CO}_{2}$ exchange in Dactylis glomerata. Ann. Bot. 38:53-62.

3. Epstein, E. 1972. Mineral nutrition of plants: Principles and perspectives. John Wiley and Sons, Inc., New York.

4. Grace, J. 1974. The effect of wind on grasses. I. Cuticular and stomatal transpiration. J. Exp. Bot. 25:542-551.

5. Hanson, W. D. 1971. Selection for differential productivity among juvenile maize plants: Associated net photosynthetic rate and leaf area change. Crop Sci. 11:334-939.

6. Horst, G. L. 1973. Physiological and growth responses of tall fescue (Festuca arundinacea Schreb.) genotypes to drought and irrigation. Ph.D. thesis, Univ. Missouri. Univ. Microfilms. Ann Arbor, MI (Diss. Abst. 34:5289-B).

7. Hoveland, C. S., H. W. Foutch, and G. A. Buchanan. 1974. Response of Phalaris genotypes and other cool-season grasses to temperature. Agron. J. 66:686-690.

8. Jewiss, O. R., and J. Woledge. 1967. The effect of age on the rate of apparent photosynthesis in leaves of tall fescue (Festuca arundinacea Schreb.). Ann. Bot. 31:664-671.

9. Kanemasu, E. T., G. W. Thurtell, and C. G. Tanner. 1969. Design, calibration, and field use of a stomatal diffusion porometer. Plant Physiol. 44:881-885.

10. Meyer, R. F., and J. S. Boyer. 1972. Sensitivity of cell division and cell elongation to low water potentials in soybean hypocotyls. Planta 108:77-87.

11. Nelson, C. J., K. H. Asay, and G. L. Horst. 1975. Relationship of leaf photosynthesis to forage yield of tall fescue. Crop Sci. 15:476-478.

12. - - - - - - and E. S. Hilderbrand. 1974. Field measurement of photosynthesis in a forage grass breeding program. Crop Sci. 14:26-28.

13. - -,- , and D. A. Sleper. 1977. Mechanisms of canopy development of tall fescue genotypes. Crop Sci. 17:449-452.

14. Peacock, J. M. 1975. Temperature and leaf growth in Lolium perenne. II. The site of temperature perception. J. Appl. Ecol. 12:115-123.

15. Rhodes, I. 1972. Yield, leaf-area index and photosynthetic rate in some perennial ryegrass (Lolium perenne $\mathbf{L}$.) selections. J. Agric. Sci. Camb. 78:509-511.

16. Treharne, K. J., and C. F. Eagles. 1970. Effect of temperature on photosynthetic activity of climatic races of Dactylis glomerata L. Photosynthetica 4:107-117.

17. Wardlaw, I. F. 1969. The effect of water stress on translocation in relation to photosynthesis and growth. II. Effect during leaf development in Lolium temultentum $\mathrm{L}$. Aust. J. Biol. Sci. 22:1-16.

18. Watts, W. R. 1974. Leaf extension in Zea mays. 111. Field measurements of leaf extension in response to temperature and leaf water potential. J. Exp. Bot. 25:1085-1096.

19. Wilhelm, W. W., and C. J. Nelson. 1978. Irradiance response of tall fescue genotypes with contrasting levels of photosynthesis and yield. Crop Sci. 17:405-408.

20. Wilson, D. 1975. Leaf growth, stomatal diffusion resistances and photosynthesis during droughting of Lolium perenne populations selected for contrasting stomatal length and frequency. Ann. Appl. Biol. 79:67-82.

21. Yoshida, S. 1972. Physiological aspects of grain yield. Annu. Rev. Plant Physiol. 23:437-464. 